\title{
OPTIMALISASI PEMANFAATAN SMARTPHONE SEBAGAI ALAT SEDERHANA DALAM MEMBUAT FILM BAGI SISWA SMA DI PEKANBARU
}

\author{
Hayatullah Kurniadi ${ }^{1)}$ Muhammad Arif ${ }^{1)}$ Nella Lucky ${ }^{1)}$ \\ Prodi Ilmu Komunikasi, Fakultas Ilmu Sosial dan Politik, Universitas Abdurrab \\ Email : hayatullahkurniadi@gmail.com
}

\begin{abstract}
ABSTRAK
Saat ini smartphone sudah memiliki fitur yang mumpuni untuk membuat film. Rata-rata smartphone yang beredar sudah dibelaki dengan kamera video dengan kualitas HD (high definition). Smartphone juga dapat dipasangkan aplikasi yang berguna untuk mengedit video. Sehingga pekerjaan pembuatan film yang awalnya dikerjakan dengan kamera profesional dan di komputer dapat dikerjakan dengan smartphone saja.

Kehadiran smartphone ini sebenarnya menjadi peluang besar bagi individu-individu yang kreatif, tidak terkecuali bagi pengguna di usia remaja seperti siswa SMA. Seharusnya bagi siswa SMA penggunaan smartphone sejatinya tidak hanya untuk kegunaan dasar seperti nelpon, sms, searching, games ataupun medsos, melainkan dapat juga digunakan sebagai alat sederhana dalam membuat produk berupa film.

Pengabdian ini berbentuk pelatihan tentang optimalisasi pemanfaatan smartphone kepada siswa SMA. Muatan pengabdian ini dalam bentuk materi, terutama yang mengarah pada kemampuan untuk dapat mengoptimalkan smartphone yang mereka miliki. Mulai dari dasar penggunaan smartphone untuk film, pengenalan aplikasi untuk membuat video dengan smartphone, pengenalan dasar-dasar teknik pengambilan gambar, praktik pengambilan gambar dengan smartphone dan pelatihan editing hingga proses finalisasi video.
\end{abstract}

Kata kunci: Optimalisasi, Smartphone dan film

\section{ABSTRACT}

Currently, smartphones have powerful features for making films. The average smartphone in circulation has been bought with a video camera with HD (high definition) quality. Smartphones can also be paired with applications that are useful for editing videos. So the filmmaking work that was initially done with a professional camera and on a computer can be done with a smartphone only.

The presence of this smartphone is actually a great opportunity for creative individuals, including young people like high school students. For high school students, the use of smartphones should not only be used for basic uses such as telephone, sms, searching, games or social media, but can also be used as a simple tool in making products in the form of films.

This service takes the form of training on optimizing the use of smartphones to high school students. The content of this service is in the form of material, especially those that lead to the ability to optimize their smartphones. Starting from the basic use of smartphones to films, the introduction of applications to make videos with smartphones, introduction to the basics of shooting techniques, practice of taking pictures with smartphones and training in editing until the process of finalizing the video.

Key words: optimization, smartphone and film 


\section{PENDAHULUAN}

Analisis Situasi

Perkembangan kamera smartphone sekarang ini ternyata tidak hanya mendukung pengambilan gambar yang lebih baik, tetapi juga video. Bahkan tak jarang beberapa pabrikan menghadirkan kemampuan perekaman video yang tidak kalah dengan kamera profesional. Kehadiran kamera smartphone dengan kualitas HD ternyata mendorong sebagian orang untuk mulai menggunakannya untuk kebutuhan khusus, salah satunya membuat film (http://tekno.liputan6.com).

Sebagai contoh pada level nasional Film yang digarap Derryl Imanalie dan David Poernomo, yaitu film Cai Lan Gong. Merupaan film yang dirilis pada tahun 2015 dibuat menggunakan Samsung Galaxi Note 4 dan Samsung Galaxi Note 5. Film ini bercerita tentang seorang perempuan yang harus menerima ilmu Cai Lan Gong dari kakeknya. Pada akhirnya film karya anak bangsa ini berhasil meraih rekor MURI Indonesia (https://www.brilio.net).

Berbeda dengan pembuatan film dengan kamera profesional, membuat film menggunakan smartphone dengan kualtas HD dapat dibilang lebih menghemat biaya produksi. Dengan smartphone proses syuting tidak membutuhkan tim yang banyak, sisanya tinggal menyesuaikan kondisi tergantung apa yang akan kita ambil (https://library.binus.ac.id). Selain itu proses editing juga dapat dilakukan melalui smartphone dengan memanfaatkan berapa aplikasi yang dapat diunduh gratis, sehingga tidak harus menggunakan komputer editing.

Dengan kelebihan yang dimiliki smartphone, maka setiap orang sebenarnya dapat memproduksi film dengan beragam bentuk, termasuk bagi anak-anak SMA. Tinggal lagi menambah pengetahuan serta mengasah kemampuan untuk membuat film tersebut. Jadi tidak hanya menjadikan smartphone sebagai tolak ukur penampilan, sekedar ikutikutan untuk bisa seperti orang lain dan hanya sebagai hiburan yang tidak memiliki arti, padahal smartphone sudah seperti candu yang mendarah daging dalam diri siswa SMA. Mereka lengket dengan diri semenjak bangun sampai mau tidur kembali (Kurniawan, 2014), maka sangat disayangkan kelebihan teknologi tersebut, jika tidak dapat dioptimalkan untuk menambah kemampuan dan bisa saja menjadi bisnis yang sangat menjanjikan dalam meraup keuntungan, jika memang ditekuni sampai professional.

Sesuai dengan analisa situasi di atas, maka rumusan masalah dalam pengabdian ini adalah "Bagaimana upaya meningkatkan softskill kemampuan siswa SMA untuk memproduksi film menggunakan smartphone yang mereka miliki sendiri?" Tujuan pengabdian ini adalah memberikan softskill kepada siswa SMA untuk membuat Film dari alat sederhana yang rata-rata saat ini mereka miliki sendiri, yaitu smartphone. Sejalan dengan tujuan di atas, maka manfaat yang didapat dari pengabdian ini adalah sebagai Ilmu dan softskill kepada siswa SMA bahwa dengan alat sederhana kita dapat membuat sebuah produk berupa film. Adapun sasaran pengabdian ini adalah siswa SMA di kota Pekanbaru

\section{TINJAUAN PUSTAKA}

\section{Tinjauan Teoritis}

Smartphone pada dasarnya adalah sebuah bentuk teknologi komunikasi lanjutan dari pendahulunya handphone yang mampu menjankan fitur layaknya personal computer. Smartphone tidak hanya berfungsi mengirimkan suara atau melakukan panggilan, melainkan juga mampu mengintegralkan hiburan seperti permainan, kemudian dapat mendokumentasikan momen dalam bentuk foto maupun video serta aplikasi lainnya 
dalam satu fisik. Smartphone bukanlah barang baru bagi masyarakat di negara-negara maju (seperti Amerika, Australia dan lain-lain) dan berkembang (seperti Negara Indonesia). Penggunaannya sudah cukup tinggi bagi masyarakat. Untuk Indonesia sendiri penyumbang pengguna smartphone terbesar adalah kalangan muda atau dapat disebut tingkat pelajar dan mahasiswa (Kurniawan, 2015).

Beberapa tahun belakangan, smartphone yang dijual dipasaran rata-rata sudah memiliki perangkat kamera untuk mengambil video. Bahkan tidak hanya satu, terdapat dua kamera dengan fungsinya masing-masing (http://membuatfilmpendek.blogspot.co. id). Umumnya film dibuat menggunakan kamera recording profesional atau minimal menggunakan kamera DSLR (kamera yang lebih sering digunakan untuk foto), namun belakangan dengan perkembangan teknologi komunikasi tersebut para kreator memiliki ide kreatif untuk membuat film hanya dengan menggunakan smartphone, terutama smartphone yang memiliki kualitas kamera HD (high definition).

Smartphone dengan kamera minimal 5MP sudah bisa digunakan untuk membuat film maupun video klip. Beberapa produk dipasaran yang sudah memiliki kamera yang bisa digunakan dalam membuat film seperti iPhone 4. Bagi pengguna Android pilihannya semakin luas, antara lain Xiaomi Mi 4, keluarga Sony Xperia Z serta Samsung Galaxy S5 dan smartphone lainnya yang memiliki kamera sama dengan atau melebihi 5 MP (https://autotekno.sindonews.com).

\section{Kerangka Pemikiran}

Adapun kerangka pemikiran kegiatan ini sebagai berikut:

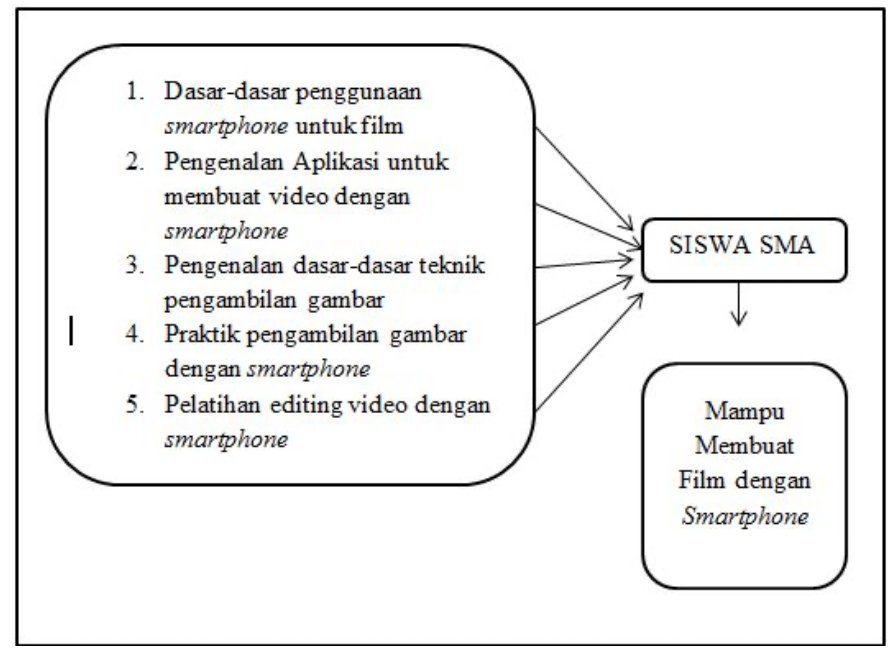

Gambar 1. Kerangka Pemikiran

\section{METODE PELAKSANAAN}

\section{Langkah Kegiatan}

Karena pengabdian ini ditujukan kepada siswa SMA, maka tim mengundang setiap sekolah untuk mengutus siswanya untuk mengikuti pengabdian ini melalui surat yang dikirimkan ke kepala sekolah.

Siswa-siswi yang diutus oleh sekolah mengikuti kegiatan ini mempersiapkan smartphone mereka masing-masing. Tim pengabdian memberitahu aplikasi yang digunakan untuk proses editing, sehingga dipastikan sudah terpasang di smartphone 
mereka. Pelaksanaan pelatihan dalam pengabdian ini dilakukan selama satu hari, dengan durasi waktu 4 jam yang diisi dengan materi tim pengabdian dengan melibatkan praktisi yang ahli dalam membuat karya video dengan smartphone.

Siswa diberikan pemahaman dasar tentang smartphone sampai teknik menggunakan kamera (pengambilan gambar) dan editing menggunakan smartphone. Setelah dibekali dengan pengetahuan tersebut, mahasiswa diberikan tugas berupa praktik pengambilan gambar (video) disekitar kampus abdurrab dengan durasi 15 menit. Kemudian video tersebut langsung diedit dengan aplikasi power director yang sebelumnya sudah terinstall.

Setelah semua melakukan proses editing video, maka masuk pada tahapan terakhir yaitu finalisasi project. Tim pengabdi, melihat karya yang dibuat oleh siswa/I tersebut dan mengevaluasinya.

\section{Teknik Penyelesaian Masalah}

Teknik Penyelesaian masalah dilakukan dengan :

a. Memberikan materi pengantar tentang smartphone.

b. Memberikan pemahaman bahwa smartphone dapat dijadikan alat sederhana untuk membuat film.

c. Memperkenalkan beragam aplikasi yang dapat digunakan untuk editing video melalui smartphone dan merekomendasikan satu aplikasi yang cukup ringan, yaitu power director.

d. Memperkenalkan teknik-teknik pengambilan gambar dengan smartphone.

e. Praktik pengambilan video dengan smartphone.

f. Praktik editing video dengan smartphone.

g. Finalisasi video.

\section{Alat Ukur Ketercapaian}

Alat ukur ketercapaian pengabdian ini berupa:

a. Siswa SMA mendapatkan pengetahuan bahwa smartphone yang mereka miliki bukanlah alat yang hanya digunakan untuk sms, nelpon, medsos, games atau berfoto saja, melainkan dapat dijadikan sebagai pembuat karya di bidang film.

b. Siswa SMA mampu mengambil gambar sesuai dengan teknik-teknik pengambilan gambar dalam perfilman.

c. Siswa SMA mampu mengoperasikan aplikasi power director sebagai aplikasi editing video dengan smartphone.

d. Siswa SMA mampu mengedit video yang diambil sampai pada proses finalisasi (menjadi produk).

\section{HASIL DAN PEMBAHASAN}

\section{Gambaran Umum Khalayak Sasaran}

Siswa SMA masuk dalam kategori usia remaja dan pemilihan sasaran ini dirasa sangat tepat, karena usia remaja adalah usia di mana sedang candu-candunya dengan smartphone. Penggunaan smartphone cendrung untuk hal-hal yang tidak bermanfaat ataupun hanya sesuai dengan fungsi dasarnya, sehingga tidak optimal.

Optimalisasi pemanfaatan smartphone ini dilaksanakan pada pelajar SMA di kota Pekanbaru. Pada awalnya ada 18 Sekolah yang diundang untuk mengutus siswa/ siswinya untuk mengikuti pengabdian ini, tetapi hanya ada enam sekolah yang berkesempatan datang. Untuk lebih jelasnya dapat dilihat pada tabel berikut : 
Tabel 1. Sasaran Pengabdian

\begin{tabular}{|l|l|}
\hline No & \multicolumn{1}{|c|}{ Nama Sekolah } \\
\hline 1. & SMAN 14 Pekanbaru \\
\hline 2. & SMAN 15 Pekanbaru \\
\hline 3. & MAN 2 Model Pekanbaru \\
\hline 4. & SMKN Pertanian Terpadu Riau \\
\hline 5. & SMP Juara Pekanbaru \\
\hline 6. & PKBM Ar-Ruhama \\
\hline
\end{tabular}

\section{Potensi Pengembangan (Pemberdayaan Masyarakat)}

Tim Pengabdian ini secara keseluruhan berasal dari Prodi Ilmu Komunikasi. Mata kuliah tentang pembuatan atau produksi video diajarkan pada prodi Ilmu Komunikasi, sehingga sangat membantu dalam hal pencapaian sasaran kegiatan. Kegiatan ini tentu dapat dikembangkan menjadi kegiatan yang lebih besar atau secara rutin diadakan oleh Prodi Ilmu Komunikasi. Dapat dilakukan dalam bentuk pengabdian seperti yang dilakukan sekarang ataupun dalam bentuk-bentuk lainnya, seperti short course ataupun workshop.

\section{Solusi Pengembangan (Pemberdayaan Masyarakat)}

Setelah dilakukan pengabdian ini siswa SMA yang ikut dapat menggunakan smartphone-nya dengan lebih optimal untuk membuat karya film (video), baik untuk mengasah kreativitas pribadi maupun dipublish untuk dinikmati oleh orang banyak atau dikomersialkan.

Membuat film merupakan skill, maka tidak cukup dengan satu kali pelatihan mereka langsung mampu membuat karya yang bagus, melainkan terus mempraktikkannya sampai mampu melakukan pengembangan dan tidak tertutup kemungkinan menjadi kreator film yang profesional.

\section{Tingkat Ketercapaian Sasaran Program}

Secara keseluruhan, tujuan kegiatan pengabdian ini tercapai, di mana seluruh siswa yang mengikuti kegiatan pada akhirnya mampu mengoptimalkan fungsi smartphonenya untuk membuat film.

\section{KESIMPULAN}

Smartphone sebagai generasi terbaru dari pendahulunya, yaitu handphone/ cellphone menawarkan beragam fungsi yang sejatinya dapat dioptimalkan oleh penggunanya. Mayoritas pengguna smartphone terutama kalangan remaja (siswa SMA) mengunakan smartphone hanya untuk nelpon, sms, searching, games ataupun medsos. Sementara smartphone saat ini sudah memiliki fitur-fitur yang canggih, salah satunya adalah kamera untuk mengambil gambar ataupun video. Kamera smartphone sudah dengan kualitas HD (high definition). Samartphone juga dapat dipasang aplikasiaplikasi yang berguna untuk mengedit video. Dengan dua kecanggihan dasar ini saja pekerjaan pembuatan film yang awalnya dikerjakan dengan kamera profesional dan komputer dapat dikerjakan dengan smartphone saja.

Fungsi smartphone seperti di atas tidak akan bisa keluar jika siswa SMA tidak mampu mengoptimalkannya. Pelatihan mulai dari dasar penggunaan smartphone untuk film, pengenalan aplikasi untuk membuat video dengan smartphone, pengenalan dasardasar teknik pengambilan gambar, praktik pengambilan gambar dengan smartphone dan 
pelatihan editing video dengan smartphone sampai pada finalisasi menjadi penting bagi pelajar, karena dengan bentuk pelatihan-pelatihan tersebut mereka dapat mengoptimalkan teknologi yang mereka genggam sendiri kearah yang lebih baik dan bermanfaat.

\section{Rekomendasi}

Siswa SMA belum mampu mengoptimalkan fungsi smartphone yang ada digenggamannya. Rata-rata fungsi smartphone hanya digunakan untuk games dan sosmed, ataupun sudah digunakan untuk mengambil video dan mengeditnya, tetapi tidak dengan kemampuan yang mumpuni, sehingga kesannya adalah video itu biasabiasa saja (tidak meliki kualitas). Pelatihan dalam bentuk pengabdian ini merupakan langkah awal bagi siswa SMA untuk dapat mengoptimalkan fungsi smartphone mereka untuk sesuatu yang positif dan bahkan bisa menghasilkan uang jika dipelajari dan dipraktikkan dengan tekun (profesional).

\section{DAFTAR PUSTAKA}

[5]. Arsyan, Alfha. 2016. Cara Membuat Film Pendek. Diakses dari http://membuatfilmpendek.blogspot.co.id/2016/11/cara-membuat-filmpendek.html, Minggu 09 April 2017.

[6]. Damar, Agustinus Mario. 2015. 4 cara mudah bikin film dengan smartphone. Diakses dari: http://tekno.liputan6.com/read/2348755/4-cara-mudah-bikin-filmdengan-smartphone, Sabtu, 03 Maret 2017.

[7]. Dewi, Andi Rosita. 2016. Tak diduga, 5 film keren ini ternyata dibikin dengan kamera handphone!. Diakses dari: https:/www.brilio.net/wow/tak-diduga-5film-keren-ini-ternyata-dibikin-dengan-kamera-handphone-160205i.html, Sabtu, 03 Maret 2017.

[8]. https://library.binus.ac.id/eColls/eThesisdoc/Bab1/2014-2-02053DS\%20Bab1001 .pdf, didownload minggu, 04 Maret 2017.

[9]. Koran Sindo. 2015. Tips Membuat Film dengan Smartphone diakses dari: https://autotekno.sindonews.com/read/1034421/128/tips-membuat-film-dengansmartphone-1439914472, Minggu 09 April 2017.

[10]. Kurniawan, Adi. 2015. Pengaruh Pemanfaatan Smartphone Terhadap Komunikasi Interpersonal Mahasiswa Ilmu Komunikasi UIN SUSKA Riau. Skripsi: UIN SUSKA Riau 